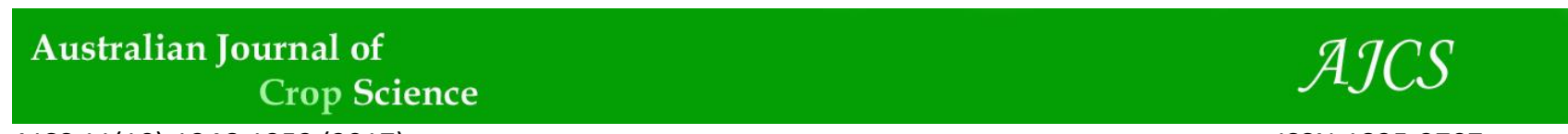

AJCS 11(10):1346-1353 (2017)

ISSN:1835-2707

doi: 10.21475/ajcs.17.11.10.pne678

\title{
Association mapping and genetic control for northern leaf blight (Exserohilum turcicum) resistance in maize lines
}

\author{
Kaian Albino Corazza Kaefer*1 ${ }^{1}$, Adilson Ricken Schuelter ${ }^{1}$, Ivan Schuster ${ }^{2}$, Jonatas Marcolin ${ }^{1}$, Eliane \\ Cristina Gruska Vendruscolo ${ }^{3}$
}

\author{
${ }^{1}$ State University of Western Paraná, Marechal Cândido do Rondon - PR, Brazil \\ ${ }^{2}$ Dow Agrociences, Cravinhos - SP, Brazil \\ ${ }^{3}$ Federal University of Paraná, Palotina - PR, Brazil
}

*Corresponding author: kaiankaefer@hotmail.com

\begin{abstract}
The aim of this work was to identify genomic regions associated with northern leaf blight resistance (Exserohilum turcicum) in common maize lines and to study the control involved in the resistance. For association mapping, 72 maize lines were previously genotyped for SNP markers on the 650K platform (Affymetrix ${ }^{\circledR}$ ), and their respective genotypic values were predicted by mixed models for northern leaf blight. In order to avoid spurious associations between SNP markers and the studied character, the analysis of population structure was initially performed. The analysis of association between the SNP and northern leaf blight markers was carried out using a linear mixed model. For the study of genetic control, the experiment was conducted in 2016 and it was composed of randomized blocks with three repetitions. Through the notes attributed to the lines and their respective generations, the genotypic data related to the inheritance of the studied disease were extracted. Analyzing the results, QTLs were found on chromosomes 1, 2, 3, 4, 6, 8, 9 and 10 for northern leaf blight in maize, which may increase, reduce or even override the effect of this attribute. Among the QTLs found, five genomic regions were detected for increased resistance to northern leaf blight with the use of SNP markers, found in chromosomes 3 (SNP210703), 8 (SNP507268 and SNP507269), 9 (SNP544616) and 10 (SNP610500). The genetic control of resistance to northern leaf blight is quantitative, with the additive effects being more important in the character determination. In addition, it presents high restricted heritability (88\%), which allows good selection efficiency and selection gains.
\end{abstract}

Keywords: Exserohilum turcicum, genetic inheritance, genetic resistance, linkage disequilibrium, Zea mays.

\section{Introduction}

The maize crop in Brazil began to face serious disease problems from the 1990s, both by increasing frequencies and by severe qualitative and quantitative damages to production (Nihei and Ferreira, 2012). This increase in the amount of diseases is highly related to changes in the production system of maize crop, such as expansion of the agricultural border, expansion of planting seasons (crop and winter crop), adoption of direct planting, increased use of irrigation systems, lack of crop rotation and use of susceptible materials (Silva et al., 2015). With regard to common maize, northern leaf blight, caused by the anomorphic fungus Exserohilum turcicum, is characterized as one of the oldest and most important foliar diseases, occurring widely in Brazil and in the main producing regions of the world (Harlapur et al., 2008; Wang et al., 2010, 2012). Losses caused by the disease under favorable environmental conditions and in susceptible cultivars can reach up to $50 \%$ of the productive potential of the crop (Schipanski, 2011). The use of genetically resistant cultivars against major maize diseases is the most efficient and viable method of control (Vieira et al., 2009). However, the development of cultivars is an intense work, since it initially involves the identification of resistance sources and the study of the genetic control of the character (Souza et al., 2004). Therefore, this information facilitates the conduction of any breeding program, due to the fact that breeders have at their disposal the possibility of choosing the most appropriate strategy, in order to direct the work of introducing resistance genes into susceptible genotypes (Falconer and Mackay, 1996). The genetic control for resistance to major leaf diseases is described as qualitative in most studies, however, there are some that can be characterized as quantitative. These two types of resistance can be found acting separately or concurrently (Ogliari et al., 2007). Quantitative or horizontal resistance is widely used in the genetic control of northern leaf blight, referring to several genes of small additive effects acting on the expression of the character (Vivek et al., 2010). However, for resistance to E. turcicum, genes of non-additive effects coming from genes under dominance and/or epistasis, have been shown to be important (Niehi and Ferreira, 2012). In this context, the quantitative resistance to northern leaf blight can be characterized also by the joint action of additive and non-additive genes (Ogliari, 2007; Vieira et al., 2009). In breeding programs, a tool that stands out for the rapidity and effectiveness in genetic studies of germplasm, has been the use of molecular marker techniques, due to the detection of polymorphism at the molecular level without taking into account environmental influence (Faleiro, 2011). With the advent of very high-level sequencing technologies, the simultaneous genotyping of thousands of SNP markers (Single Nucleotide Polymorphism) 
at lower costs and the increase of computational analysis capacity, it has become possible to develop new genetic mapping methods, among them the genetics of association (Xu et al., 2009). The genetics of association, also known as association mapping, or linkage disequilibrium mapping, is based on statistically evaluating the linkage disequilibrium between the marker and the QTL, which are variations caused by mutations and amplified by recombination during the evolution of species (Resende Júnior et al., 2013). In this way, this strategy applied to the plant improvement emerges as an important methodology to map genes of interest, providing more relevant and accurate information for the selection of genotypes (Castro and Pereira, 2008). Studies using this methodology are being widely used for studies of resistance to maize foliar diseases, such as northern leaf blight (Poland et al, 2011; Van Inghelandt et al, 2012; Ding et al, 2015.).

In view of the aforementioned, the aim of this study was to identify genomic regions associated with resistance to northern leaf blight in common maize lines and to study the genetic control involved in resistance.

\section{Results and Discussion}

\section{Association mapping for the resistance to northern leaf blight}

Through association mapping analysis, based on the mixed linear model (MLM), 46 associations were identified for northern leaf blight (probability of $0.05 \%$ or $[-\log 10$ (Pvalue) $\geq 3.0$ ), distributed on chromosomes $1,2,3,4,6,8,9$ and 10 of maize $(n=10)$. Thus, there was a greater predominance of associations on chromosome 3 (12 associations), followed by chromosome 9 (9 associations), chromosome $6 \quad$ (8 associations), chromosome $10 \quad(5$ associations), chromosomes 2 and 8 (4 associations) and chromosomes 1 and 4 ( 2 associations).

With the estimated values for each SNP marker associated with northern leaf blight, there is a high number of falsepositive associations $([-\log 10(\mathrm{P}$-value $)] \leq 3.0)$ distributed throughout the maize genome (Fig 1). Considering a minimum $\mathrm{P}$-value of $0.05 \%$, it is possible to detect a strong tendency of associations in chromosomes 3, 6, 8 and 10 (Fig 1).

Selecting the twenty SNP with the highest determination coefficients for NLB (variation from 0.277 to 0.231), a greater predominance on chromosome 3 of maize is observed, in addition to the higher magnitudes found $(0.297$ and 0.291) (Table 1). Despite the predominance of the markers on chromosome 3, it is observed that the SNP205575, SNP205576, SNP205577 and SNP205579 are acting on the same genomic region, since the genetic distance is relatively low among them (variation of $1.37 \mathrm{~Kb}$ ). In this way, because they are very close to each other, the effect of one marker may be contaminating the effect of the other, presenting redundant information.

In allogamous species, the extent of linkage disequilibrium (LD) is relatively short ( 0.4 to $2.0 \mathrm{~Kb})$ and declines rapidly, requiring a substantially large number of markers to detect an association (Malosetti et al., 2007). The LD decline occurs when samples are derived primarily from traditional varieties and lines, because the variation in the extent of linkage disequilibrium is highly dependent not only on the specific genomic region but also on the population used to quantify it (Borém and Caixeta, 2009).

In relation to the effect of the A and B alleles of the SNP markers, there was a predominance of associations to reduce the magnitude of the disease values, with the exception of the markers SNP211587 and SNP225204 (chromosome 3), and SNP562142 (chromosome 9) (Table 1). The reduction of the magnitude of the NLB values is desirable, since it promotes a reduction of severity caused by the disease, thus contributing to the development of more resistant strains.

Analyzing the Manhattan chart (Fig1) and the table with the twenty largest determination coefficients (Table 1), five genomic regions were found to promote increased resistance to northern leaf blight: a QTL (SNP210703) located on chromosome 3, a QTL (SNP427898) on chromosome 6, a QTL (SNP507268 and SNP507269) on chromosome 8, a QTL (SNP544589 and SNP544616) on chromosome 9 and a QTL (SNP610500) on maize chromosome 10. In the present study, we used QTLs on these chromosomes, as well as a QTL on chromosome 3 (Ogliari et al., 2007) and a QTL on chromosome 8 (Chung et al., 2010a; 2010b; Wang et al., 2012).

Recently, works with association mapping have been developed in order to identify associations between molecular markers and phenotypes of interest with more saturated maps (Moreira et al., 2009). Papers using this method have been widely used for studies of resistance to maize leaf diseases, such as for NLB (Poland et al., 2011; Van Inghelandt et al., 2012, Ding et al., 2015).

Corroborating the work, Ding et al. (2015) when studying association mapping for new sources of resistance to northern leaf blight in maize, identified 12 genes associated with the disease on chromosomes 1, 2, 3, 4, 7, 9 and 10 of maize. Among the genes identified, five are associated with two or three regions of resistance, one gene on chromosome 4, two genes on chromosome 7 and two genes on chromosome 10 . With respect to the five strains that are more resistant and susceptible to HT from maize, it can be noted the existence of genomic regions that share common resistance alleles, such as chromosome 3 (SNP210703), 8 (SNP507268 and SNP507269), 9 (SNP544616) and 10 (SNP610500) (Table 1). With regard to the level of resistance, it is observed that the resistant strains showed negative genomic values (above 122), when compared to the susceptible ones that showed negative genomic values (below -90), evidencing the difference of allelic composition of tolerant and sensitive materials to northern leaf blight (Table 1)

Bearing this in mind, the knowledge of the regions associated with the disease in question, along with the practicality of application of the methodology, without the need for crossing, allows the breeder to identify resistant genotypes more quickly and accurately, in order to use them as sources of resistance to the development of new commercial hybrids. In addition, it is possible to carry out genetic control studies in order to know the magnitude of the variability and the gene effects involved in the character of interest, through the choice of contrasting materials, such as the CD15 and CD69 lines.

\section{Genetic inheritance of northern leaf blight resistance}

The study was conducted under favorable environmental conditions in order to provide the natural infestation of maize northern leaf blight. Therefore, it is advisable to note that the maximum incidence and severity indexes in this study were about 0 to $75 \%$ in leaves of the upper middle third of the plant with lesions (grades ranged from 1 to 5), allowing a representative discrimination of the resistance levels. This amplitude of severity was equal to or greater than the studies of northern leaf blight under natural infestations (Viera et al., 2009; Nihei and Ferreira, 2012). 
Table 1. Association analysis with the twenty largest genotypic determination coefficients for the five most resistant lines and susceptible to northern leaf blight (Cascavel/PR, 2016).

\begin{tabular}{|c|c|c|c|c|c|c|c|c|c|c|c|c|c|c|c|c|c|c|}
\hline \multirow{2}{*}{ MARC. } & \multirow{2}{*}{ CR. } & \multirow{2}{*}{ POSITION } & \multirow{2}{*}{ DIST. (Kb) } & \multirow{2}{*}{$\mathrm{F}$} & \multirow{2}{*}{ PROB. } & \multirow{2}{*}{ R2 (\%) } & \multirow{2}{*}{ EFFECT A } & \multirow{2}{*}{ EFFECT B } & \multicolumn{5}{|c|}{ RESISTENT STRAINS } & \multicolumn{5}{|c|}{ SUSCEPTIBLE STRAINS } \\
\hline & & & & & & & & & 2 & 15 & 28 & 30 & 41 & 16 & 33 & 52 & 63 & 69 \\
\hline SNP116035 & 2 & 45971994 & 0 & 3.34 & 0.00034 & 26.5 & -0.23 & 0.71 & AA & AA & $\mathrm{AA}$ & $\mathrm{AA}$ & AA & AA & BB & AA & $\mathrm{AA}$ & BB \\
\hline SNP195833 & 3 & 97896759 & 0 & 0.86 & 0.00050 & 24.9 & -1.13 & 0.00 & BB & $\mathrm{BB}$ & $\mathrm{BB}$ & BB & BB & BB & AA & $\mathrm{BB}$ & BB & AA \\
\hline SNP205575 & 3 & 137387675 & 39491 & 10.25 & 0.00140 & 29.7 & 0.62 & -0.67 & BB & BB & BB & BB & BB & BB & AA & BB & AA & AA \\
\hline SNP205576 & 3 & 137388596 & 39492 & 10.25 & 0.00140 & 29.7 & 0.62 & -0.67 & BB & BB & BB & BB & BB & BB & AA & BB & $A A$ & $A A$ \\
\hline SNP205577 & 3 & 137388601 & 39492 & 10.25 & 0.00140 & 29.7 & 0.62 & -0.67 & BB & BB & BB & BB & BB & BB & AA & BB & $A A$ & AA \\
\hline SNP205579 & 3 & 137389050 & 39492 & 10.05 & 0.00016 & 29.1 & 0.79 & -0.46 & BB & BB & BB & BB & BB & BB & AA & BB & AA & AA \\
\hline SNP210703 & 3 & 154753924 & 56857 & 8.04 & 0.00078 & 23.3 & -18.99 & 0.00 & AA & AA & AA & $A A$ & AA & BB & BB & BB & $A A$ & BB \\
\hline SNP211587 & 3 & 157577589 & 59681 & 9.21 & 0.00920 & 25.3 & 1.21 & 0.00 & BB & BB & BB & BB & BB & BB & AA & BB & AA & AA \\
\hline SNP225204 & 3 & 194547063 & 96650 & 16.48 & 0.00013 & 23.9 & 0.84 & 0.00 & BB & BB & AA & BB & BB & AA & AA & AA & BB & AA \\
\hline SNP256995 & 4 & 51493267 & 0 & 0.83 & 0.00600 & 24.2 & -1.66 & -10.80 & AA & $\mathrm{BB}$ & BB & AA & $\mathrm{BB}$ & AA & AA & $\mathrm{BB}$ & $\mathrm{BB}$ & BB \\
\hline SNP258064 & 4 & 55249726 & 3756 & 8.27 & 0.00060 & 24.0 & -1.36 & -15.55 & BB & AA & BB & BB & BB & AA & AA & AA & BB & $A A$ \\
\hline SNP427898 & 6 & 167397069 & 0 & 8.48 & 0.00055 & 24.6 & -12.09 & -1.15 & AA & AA & AA & BB & BB & BB & BB & BB & BB & BB \\
\hline SNP507268 & 8 & 117972160 & 0 & 8.38 & 0.00059 & 24.3 & -12.22 & -1.91 & AA & AA & AA & AA & AA & AA & AA & AA & BB & BB \\
\hline SNP507269 & 8 & 117972299 & 0 & 8.38 & 0.00598 & 24.3 & -19.11 & -12.22 & AA & $A A$ & AA & $A A$ & AA & BB & BB & BB & BB & BB \\
\hline SNP507280 & 8 & 118004292 & 32 & 8.38 & 0.00059 & 24.3 & -12.22 & -1.91 & BB & $\mathrm{BB}$ & $\mathrm{BB}$ & AA & $\mathrm{BB}$ & BB & AA & AA & BB & BB \\
\hline SNP544435 & 9 & 58059517 & 0 & 8.17 & 0.00070 & 23.7 & -1.25 & -10.68 & BB & AA & $\mathrm{BB}$ & $\mathrm{AA}$ & $\mathrm{BB}$ & BB & BB & $\mathrm{BB}$ & AA & BB \\
\hline SNP544589 & 9 & 58575058 & 516 & 7.98 & 0.00081 & 23.1 & -15.45 & -14.62 & BB & $A A$ & BB & BB & $\mathrm{BB}$ & BB & BB & $\mathrm{BB}$ & BB & BB \\
\hline SNP544616 & 9 & 58727966 & 668 & 8.33 & 0.00620 & 24.1 & -13.89 & -14.20 & BB & $\mathrm{BB}$ & BB & BB & BB & BB & AA & $\mathrm{BB}$ & $A A$ & $A A$ \\
\hline SNP562142 & 9 & 126946209 & 68887 & 8.55 & 0.00520 & 24.8 & 0.51 & 1.53 & AA & BB & BB & $A A$ & AA & BB & BB & BB & AA & AA \\
\hline SNP610500 & 10 & 137502274 & 0 & 8.13 & 0.00070 & 23.5 & -13.06 & -0.17 & AA & $\mathrm{AA}$ & AA & AA & AA & $\mathrm{BB}$ & BB & $\mathrm{BB}$ & $\mathrm{BB}$ & BB \\
\hline GENOMIC VA & & & & & & & & & -135 & -122 & -144 & -126 & -134 & -70 & -74 & -90 & -88 & -64 \\
\hline
\end{tabular}

MAR. = SNP markers; $\mathrm{CHR} .=$ Chromosome; $\mathrm{Kb}=$ Kilobase $; \mathrm{F}=$ Tabulated value of F; PROB. = Probability; $\mathrm{R}^{2}=$ Determination coefficient; EFFECT A = Effect of allele A; EFFECT B = Effect of allele $\mathrm{B}$

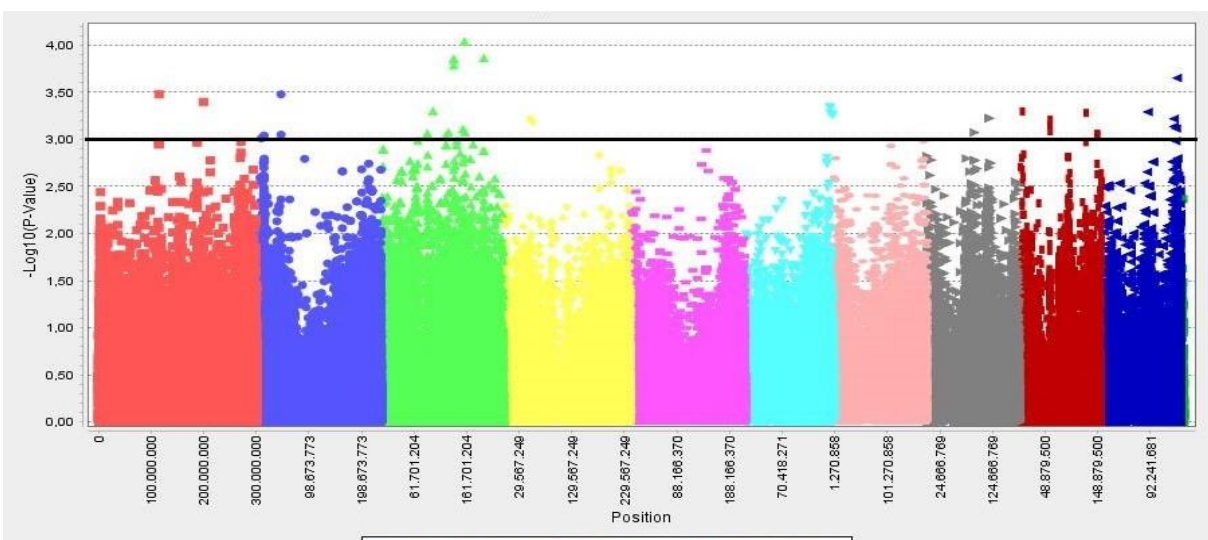

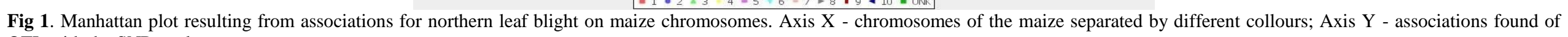
QTL with the SNP marker. 
Table 2. Number of plants phenotypically evaluated, average of severity (sev), variances $\left(\sigma^{2}\right)$ and the average severity variances $\mathrm{V}$ (sev) for resistance to northern leaf blight.

\begin{tabular}{lllll}
\hline GENERATION & $\mathrm{N}^{\mathrm{o}}$ OF PLANTS & AVERAGE $(\mathrm{sev})$ & VARIANCES $\left(\sigma^{2}\right)$ & $\mathrm{V}(\mathrm{sev})$ \\
\hline $\mathrm{P}_{1}$ & 12 & 4.5833 & 0.2651 & 0.0220 \\
$\mathrm{P}_{2}$ & 12 & 1.3333 & 0.2424 & 0.0202 \\
$\mathrm{~F}_{1}$ & 12 & 3.9166 & 0.0833 & 0.0069 \\
$\mathrm{~F}_{2}$ & 150 & 3.3266 & 0.8925 & 0.0059 \\
$\mathrm{RC}_{1}$ & 48 & 4.3541 & 0.2335 & 0.0048 \\
$\mathrm{RC}_{2}$ & 48 & 2.7916 & 0.7641 & 0.0159 \\
\hline
\end{tabular}

Table 3. Estimation of phenotypic variance, genotypic, additive, dominance, and the environment, heritability broad and restricted sense, the average degree of dominance and the estimated number of genes for northern leaf blight resistance.

\begin{tabular}{lc}
\hline PARAMETER & NORTHERN LEAF BLIGHT \\
\hline Phenotypic variance $\left(\hat{\sigma} p^{2}\right)$ & 0.8925 \\
Genotypic variance $\left(\hat{\sigma} g^{2}\right)$ & 0.8092 \\
Additive variance $\left(\widehat{\sigma} a^{2}\right)$ & 0.7873 \\
Dominance variance $\left(\hat{\sigma} d^{2}\right)$ & 0.0218 \\
Environment variance $\left(\hat{\sigma} e^{2}\right)$ & 0.0833 \\
Heritability broad sense $\left(\widehat{h} b^{2}\right)$ & 0.9066 \\
Heritability restricted sense $\left(\hat{h} r^{2}\right)$ & 0.8821 \\
Average degree of dominance $($ based on variances) & 0.2357 \\
Number of genes & 2.54 \\
\hline
\end{tabular}

Table 4. Non-orthogonal decomposition of the sum of squares of parameters (m, a, d, aa, ad, dd), by the Gauss elimination method of the characteristic resistance to northern leaf blight.

\begin{tabular}{lccc}
\hline VARIATION SOURCE & DEGREE OF FREEDOM & SUM OF SQUARES & $\mathrm{R}^{2}(\%)$ \\
\hline $\mathrm{m} / \mathrm{a}, \mathrm{d}, \mathrm{aa}, \mathrm{ad}, \mathrm{dd}$ & 1 & 20.6109 & 7.09 \\
$\mathrm{a} / \mathrm{m}, \mathrm{d}, \mathrm{aa}, \mathrm{ad}, \mathrm{dd}$ & 1 & 249.7164 & 86.00 \\
$\mathrm{~d} / \mathrm{m}, \mathrm{a}, \mathrm{aa}, \mathrm{ad}, \mathrm{dd}$ & 1 & 9.7791 & 3.36 \\
$\mathrm{aa} / \mathrm{m}, \mathrm{a}, \mathrm{d}, \mathrm{ad}, \mathrm{dd}$ & 1 & 5.4398 & 1.87 \\
$\mathrm{ad} / \mathrm{m}, \mathrm{a}, \mathrm{d}, \mathrm{aa}, \mathrm{dd}$ & 0.1245 & 0.04 \\
$\mathrm{dd} / \mathrm{m}, \mathrm{a}, \mathrm{d}, \mathrm{aa}, \mathrm{ad}$ & 1 & 4.6812 & 1.61 \\
\hline TOTAL & 1 & 290.3521 & \\
\hline
\end{tabular}

$\mathrm{m}$ - average estimates; a - additive gene effects; d - dominant gene effects; aa - epistatic additive-additive; ad - epistatic additive-dominant; dd - epistatic dominantdominant.

Table 5. Non-orthogonal decomposition of the sum of squares of parameters ( $m, a, d)$, by the Gauss elimination method of the characteristic resistance to northern leaf blight.

\begin{tabular}{lccc}
\hline PARAMETER & DEGREES OF FREEDROM & SUM OF SQUARES & $\mathrm{R}^{2}(\%)$ \\
\hline $\mathrm{m} / \mathrm{a}, \mathrm{d}$ & 1 & 1377.7305 & 74.30 \\
$\mathrm{a} / \mathrm{m}, \mathrm{d}$ & 1 & 423.3156 & 20.83 \\
$\mathrm{~d} / \mathrm{m}, \mathrm{a}$ & 1 & 53.0880 & 2.86 \\
\hline TOTAL & 3 & 1854.1342 & \\
\hline
\end{tabular}

$\mathrm{m}$ - average estimates; $\mathrm{a}$ - additive gene effects; $\mathrm{d}$ - dominant gene effects 
Analyzing the averages of the parents (Table 2), it can be observed that the parental 1 and 2 were highly contrasting, since they presented totally divergent average values for the disease in question. The $F_{1}$ and $F_{2}$ generations presented median severity averages to the parents and the average of backcrossing tended to approximate the averages of the lines used as the recurrent parent (Table 2). Moreover, no transgressive segregation is observed in the $F_{2}$ generation, in other words, values of the segregating generation phenotypes do not exceed the limits established by the corresponding parental values. Such averages of generations are indications that additive effects are involved in the genetic control of northern leaf blight.

It is observed that in the variances of the NLB populations (Table 2), the generations of the parents $\left(\mathrm{P}_{1}\right.$ and $\left.\mathrm{P}_{2}\right), \mathrm{F}_{1}$ and $\mathrm{RC}_{1.2}$ had the lowest values. These smaller values occur due to the fact that the respective generations $\left(\mathrm{P}_{1}, \mathrm{P}_{2}\right.$ and $\left.\mathrm{F}_{1}\right)$ have the same genotype, and any variation that occurs between the plants is of an environmental nature. The other segregating generations $\left(\mathrm{RC}_{1.1}\right.$ and $\left.\mathrm{F}_{2}\right)$, with the exception of $\mathrm{RC}_{1.2}$, present the highest values of variance (Table 2). The low value of the variance found for backcrossing with genitor 2 $\left(\mathrm{RC}_{1.2}\right)$ can also be explained, due to the fact that each sampled value performed in the study is composed of an average of four plants evaluated phenotypically, thus contributing to the decrease of the variance values of the generations.

It is verified that the genetic constitution provided the major contribution to the expression of northern leaf blight $\left(\hat{\sigma}_{g}^{2}=0,8092\right)$, bearing in mind that there was a low environmental influence $\left(\hat{\sigma}_{e}^{2}=0,0833\right)$ (Table 3$)$. In addition, the major genotypic contribution was derived from the additive component $\left(\hat{\sigma}_{\alpha}^{2}=0,7873\right)$, while the deviations

of dominance represented relatively less importance $\left(\hat{\sigma}_{d}^{2}=0,0218\right)$.

Information about the magnitude of the additive variance and the deviations of dominance, neglecting the one of epistatic nature, allows the breeder to evaluate the potentiality of the studied population, besides the fact that it facilitates the choice of the most efficient selection method to be employed. Thus, the existence of the additive variance constitutes an indication of the ease of identification of superior genotypes, unlike the variance attributed to the dominance deviations, which is an indicator of the difficulties in the selective process, both in terms of identification of genotypes and in quantity of gains by selection (Cruz et al., 2012).

One of the genetic parameters most used by breeders is the estimation of heritability, since it allows the prediction of the possibility of success with the selection (Borém and Miranda, 2013). It is observed that heritability in the broad and restricted sense for resistance to northern leaf spot were $90.66 \%$ and $88.21 \%$, respectively (Table 3 ). Thus, it can be concluded that $90.66 \%$ of the total variation in generation F2 is due to genetic causes, and that $88.21 \%$ is attributed to the genetic cause of additive nature. The genetic component attributed to dominance has less importance when compared to the additive component, since it represents only $2.69 \%$ of the genotypic variance. Corrosion with the results, similar heritability was found for resistance to northern leaf blight, ranging from 50 to $85 \%$ (Hakiza et al., 2004; Arnhold, 2008; Santos, 2016).

The genetic control of resistance to northern leaf blight is quantitative (Table 3), and the average degree of dominance shows the existence of partial dominance (estimated value 0.2357). Quantitative resistance has the advantage of presenting partial control against practically all breeds and it also provides higher difficulty of overcoming by new breeds of the pathogen (Carson, 2006). Previous studies have demonstrated the importance of quantitative resistance to northern leaf blight control studies (Carson, 1995; Vivek et al., 2010). However, for northern leaf blight, genetic control can be carried out by quantitative resistance with predominant additive gene action and by qualitative resistance, derived from a few non-additive action genes (Ferguson and Carson, 2007). These two types of resistance can be found acting separately or concurrently (Ogliari et al., 2007). The results indicate the existence of approximately 2.5 genes acting in the genetic control of the disease (Table 3). A similar result was found by Hakiza et al. (2004), who found two to three genes contributing partially to the resistance. Therefore, Cruz et al. (2012) advise to interpret with caution the estimation of the number of genes, due to the fact that it can provide estimates with different values.

The prevalence of additivity is proven when analyzing the non-orthogonal decomposition of the sum of squares of parameters. It was observed that the additive effects were more important in character determination, since they explained $86 \%$ of the variability of the character studied (Table 4). This fact represents the possibility of obtaining resistant, more durable and stable genotypes through simple breeding strategies, such as recurrent selection and backcrossing (Vieira, 2010).

According to the non-orthogonal decomposition analysis of the sum of the squares of the parameters (Table 5), the results show that the average and the additive gene effect presented the highest magnitude estimates. Thus, both the average and variance analyzes show that the additive variability present in the F2 generation is relatively higher than that attributed to the dominance deviations.

The predominance of additive genetic action has already been verified in studies of inheritance of northern leaf blight resistance (Carson, 1995; Vivek et al., 2010). Varying from the found results, some of these studies showed a predominance of non-additive effects (Carson, 2006; Niehi and Ferreira, 2012; Santos, 2016). These two types of resistance can be found commonly acting together under the action of both additive (quantitative resistance) and nonadditive effects (referring to qualitative resistance, derived from genes under the effects of dominance and epistasis) (Vieira et al., 2009). The action of additive and non-additive effects has also been shown to be important to confer resistance to northern leaf blight (Ogliari et al., 2007; Vieira et al., 2009).

The genetic variability of the resistance to northern leaf blight is conferred to a greater extent by the additive effects, which represents not only the ease of selection of superior genotypes, but also satisfactory selection gains (Cruz et al., 2012). One of the contributions of quantitative genetics to plant breeding is the possibility for breeders to predict selection gain estimates (Ramalho et al., 2012). Considering that the selection was performed in generation F2 and with a selection intensity of $20 \%$ ( $i=1.39$ ), a gain of $4.39 \%$ was estimated for the first cycle after selection. This corresponds to approximately $35 \%$ of gain per cycle. This gain was higher than that obtained in the work of Arnhold (2008), with predicted gain of $6.27 \%$ for northern leaf blight, respectively.

\section{Materials and methods}

The experiments were carried out in the experimental field and in the laboratory of Biotechnology of the company COODETEC - Cooperativa Central de Pesquisa Agrícola 


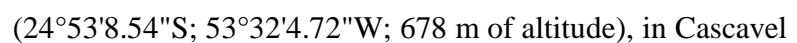
- PR, Brazil.

\section{Plant materials}

It was used 72 COODETEC maize lines, being denominated CD01 to CD72. These strains are composed by different levels of resistance to northern leaf blight in maize.

In addition, for the study of the genetic control, two strains were chosen because they differed in resistance to northern leaf blight, in other words, one resistant strain (CDL 15 genitor 1) and another highly susceptible to the disease under study (CDL 69 - genitor 2). Using controlled pollinating procedures, the seeds of the genitor lines, as well as the $F_{1}$ generations, were obtained in the winter crop of 2015 and in the next harvest, corresponding to the harvest of 2015/16 the generation $\mathrm{F}_{2}$ and the backcrossing, $\mathrm{RC}_{1.1}\left(\mathrm{~F}_{1} \times \mathrm{P}_{1}\right)$ and $\mathrm{RC}_{1.2}$ $\left(\mathrm{F}_{1} \times \mathrm{P}_{2}\right)$.

\section{Association mapping}

The experiment was conducted in a randomized block design with three repetitions (2013, 2014 and 2015), composed of one agricultural year each repetition, in order to perform the phenotyping for northern leaf blight in 72 COODETEC maize lines. The lines were evaluated as for leaf lesions in the grain filling phase, using the following evaluation method: grade1: no lesions; grade 2: sparse lesions on the plant; grade 3: up to $50 \%$ of the leaves with lesions, detecting severe lesions in $25 \%$ of the lower leaves; grade 4: up to $75 \%$ of the leaves with lesions, detecting severe lesions in $50 \%$ of the lower leaves; grade 5: $100 \%$ of leaves with lesions, with severe lesions in $75 \%$ of the lower leaves; and grade 6: dead plant. Thus, from the grades attributed to northern leaf blight, we predicted the genotypic values based on model 21 of SELEGEN-REML/BLUP software (Resende, 2008).

Genotyping for northern leaf blight was also performed in 72 COODETEC maize lines. The extraction, purification and quantification of the genomic DNA of the lines followed the Doyle and Doyle protocol. Genotyping with SNP markers was performed with the $650 \mathrm{~K}$ Platform (Affymetrix ${ }^{\circledR}$ ). Of the total of 616,201 SNP markers, 418,287 markers showed polymorphic and with high resolution in the samples used. Population structure analysis was performed initially, in order to avoid false-positive associations between markers and the studied trait. In this way, the Markov Chain Monte Carlo algorithm (MCMC) was used for the generalized Bayesian model, through InStruct software (Gao et al., 2007). The use of the MCMC algorithm has the advantage that it does not need the population to be in Hardy-Weinberg equilibrium.

In order to obtain a good convergence of the data, the allele frequencies were estimated for each number of simulated subpopulations $(k)$ and subsequently, the probability of the line $i$ was considered to belong to a population $\mathrm{k}$. Thus, burnin of 5000 simulations with 50 thousand repetitions (Run Length Periods) were used, and eight possibilities of subgroupings were tested. The best value of $k$ is the one with the highest value of $\ln \operatorname{Pr}(\mathrm{x} \mid \mathrm{k})$ between all simulated $k$ values.

The analysis of association between the SNP markers and northern leaf blight (NLB) was performed using the mixed linear model (MLM), using the statistical software TASSEL version 5.2.12 (Bradbury et al., 2007).

The significance of the associations between the SNP markers and the NLB phenotypic attribute was determined by identifying the highest values of $-\log 10(\mathrm{P})$. The $-\log 10(\mathrm{P})$ were used to obtain Manhattan Plot graphics.

\section{Study of the genetic control}

The experiment was conducted in the winter crop in 2016, using two lines derived from the study of the lineage characterization of the COODETEC maize breeding program. The experimental design was composed of randomized blocks with three repetitions, the treatments being represented by the generations. Seeding was carried out on March 7, 2016, corresponding to the winter crop of 2016. The experimental unit consisted of two rows of $5 \mathrm{~m}$ for the parent generations $\left(\mathrm{P}_{1}\right.$ and $\left.\mathrm{P}_{2}\right)$ and $\mathrm{F}_{1}$, four rows of $5 \mathrm{~m}$ for the generations $\mathrm{RC}_{1.1}$ and $\mathrm{RC}_{1.2}$ and eight rows of $5 \mathrm{~m}$ for generation $F_{2}$, with 20 plants/street and spacing of $0.5 \mathrm{~m}$ between rows. As a border, we used four rows of hybrids highly susceptible to foliar diseases. In addition, maize stalks with foliar disease lesions were placed between the rows in order to promote greater disease pressure in the experimental area.

Within the randomized block experiment, it was necessary to perform individual marking of the plants for each generation, so that they could later be assessed. Because of the different segregation for each generation, 12 plants were tagged for each genotype generation $\left(\mathrm{P}_{1}\right.$ and $\left.\mathrm{P}_{2}\right)$ and $\mathrm{F}_{1}, 48$ plants for each backcrossing $\left(\mathrm{RC}_{1.1}\right.$ and $\left.\mathrm{RC}_{1.2}\right)$ and 150 plants for $\mathrm{F}_{2}$, according to the recommendations of Cruz et al. (2012). The cultural treatments were carried out according to the recommendations of the culture, except for the application of fungicides (Embrapa, 2010)

The infection of the disease occurred naturally in the field and later, it was evaluated according to the foliar lesions in the phase of filling of grains (32 days after flowering), with the aid of the descriptive key previously mentioned (grades from 1 to 6 ).

By means of the resistance grades to northern leaf blight attributed to the lines and their respective generations, the genotypic data related to the inheritance of the studied disease were extracted.

Genetic studies on the resistance inheritance of northern leaf blight, based on population means and variances, were performed as described by Mather and Jinks (1982). Estimates of genetic and environmental parameters, based on the analysis of the variances of the segregating and nonsegregating generations, were performed according to Cruz et al. (2012). The means of the segregating and non-segregating generations were used to estimate the effects involved in the determination of the genetic resistance to northern leaf blight using the weighted least squares method (Mather and Jinks, 1982; Cruz et al., 2012). The statistical procedures were performed using the GENES software application (Cruz, 2006).

\section{Conclusion}

With the exception of chromosomes 5 and 7, significant associations to northern leaf blight were detected in the other chromosomal regions, which may increase, reduce or even cancel the effect of this attribute. Among the QTLs found, five genomic regions were detected to increase resistance to northern leaf blight with the use of SNP markers, which were found on chromosomes 3, 6, 8, 9 and 10. The genetic control of northern leaf blight resistance is quantitative, with the additive effects being the most important in character determination. Moreover, it presents high restricted heritability $(88 \%)$, which allows good efficiency in selection and in selection gains. 


\section{Acknowledgements}

The authors thank Cooperativa Central de Pesquisa Agrícola - COODETEC, for the availability of the infrastructure of the company and execution of the experiment, and also UNIOESTE and CAPES, for the granting of a master's degree scholarship to the first author.

\section{References}

Arnhold E (2008) Seleção para resistência a doenças foliares em famílias S1 de milho pipoca. Ceres. 55: 89-93.

Borém A and Caixeta ET (2009) Marcadores moleculares. Viçosa, MG: Editora Folha de Viçosa. 532p.

Borém A and Miranda GV (2013) Melhoramento de plantas. 5.ed. Viçosa: UFV. 523p.

Bradbury PJ, Zhang Z, Kroon DE, Casstevens TM, Ramdoss Y, Buckler ES (2007) Tassel: software for association mapping of complex traits in diverse samples. Oxford J Sci Math Bioinfo. 23: 2633-2635.

Carson ML (2006) Response of a maize synthetic to selection for components of partial resistance to Exserohilum turcicum. Plant Dis. 90: 910-914.

Carson ML (1995) A new gene in maize conferring the chlorotic halo reaction to infection by Exserohilum turcicum. Plant Dis. 79: 717-720.

Castro CM and Pereira AS (2008) Mapeamento por associação em plantas: conceitos básicos e perspectivas de uso no melhoramento de batata. Pelotas: Embrapa Clima Temperado. 30p. (Documentos, 248).

Chung CL, Jamann T, Longfellow J, Nelson R (2010a) Characterization and fine-mapping of a resistance locus for northern leaf blight in maize bin 8.06. Theor Appl Genet. 121: 205-227.

Chung CL, Longfellow JM, Walsh EK, Kerdieh Z, Van Esbroeck G (2010b) Resistance loci affecting distinct stages of fungal pathogenesis: use of introgression lines for QTL mapping and characterization in the maizeSetosphaeria turcica pathosystem. BMC Plant Biol. 10: 103-127.

Cruz CD (2006) Programa genes - Biometria. 1st ed. Viçosa: UFV.

Cruz CD, Regazzi AJ, Carneiro PCS (2012) Modelos biométricos aplicados ao melhoramento genético. 4. ed. Viçosa: Editora UFV. v. 2. 514p.

Ding J, Ali F, Chen G, Li H, Mahuku G, Yang LN, Magarokosho C, Makumbi D, Yan J (2015) Genome-wide association mapping reveals novel sources of resistance to northern corn leaf blight in maize. BMC Plant Biol. 15: 206.

Doyle JJ and Doyle JL (1990) Isolation of plant DNA from fresh tissue. Focus. 12: 13-15.

Embrapa (2010) Cultivo do milho. Sete Lagoas: Embrapa. (Manual técnico).

Falconer DS and Mackay TFC (1996) Introduction to quantitative genetics. 4.ed. Edinburgh: Longman Group Limited. 464p.

Faleiro FG (2011) Aplicações de marcadores moleculares como ferramenta auxiliar em programas de conservação, caracterização e uso de germoplasma e melhoramento genético vegetal. In: Faleiro FG, Andrade SEM, Reis Junior FB (Eds). Biotecnologia estado da arte e aplicações na agropecuária. 3: 55-120.

Ferguson LM and Carson ML (2007) Temporal variation in Setosphaeria túrcica between 1974 and 1994 and origin of races 1, 23, and 23N in the United States. Phytopathology. 97: $1501-1511$.
Gao H, Mcdonnell A, Harrison DA, Moore T, Adam S, Daly K, Esmonde L, Goldhill DR, Parry GJ, Rashidian A, Subbe CP, Harvey S (2007) Systematic review and evaluation of physiological track and trigger warning systems for identifying at-risk patients on the ward. ICM J. 33: 6676679.

Hakiza JJ, Lipps PE, Martin SST, Pratt RC (2004) Heritability and number of genes controlling partial resistance to Exserohilum turcicum in maize inbred H99. Maydica. 49: 173-182.

Harlapur SI, Kulkarni MS, Wali MC, Srikant K, Yashoda H, Patil BC (2008) Status of turcicum leaf blight of maize in Karnataka. Karnataka. J Agr Sci. 21: 55-60.

Malosetti M, van der Linden CG, Vosman B, van Eeuwijk FA (2007) A mixed-model approach to association mapping using pedigree information with an illustration of resistance to Phytophthora infestans in potato. Genetics. 175: 879-889.

Mather SK and Jinks JL (1982) Biometrical genetics. Cambridge: Cambridge University Press. 396p.

Moreira JUV, Vieira DA, Souza BAP, Souza Júnior CL (2009) QTL mapping for reaction to phaeosphaeria leaf spot in a tropical maize population. Theor Appl Genet. 119: 1361-1369.

Nihei TH and Ferreira JM (2012) Análise dialélica de linhagens de milho com ênfase na resistência a doenças foliares. Pesquisa Agropecuária Brasileira. 47: 369-377.

Ogliari JB, Guimarães MA, Giraldi IO, Carmargo LEA (2007) New resistance genes in the Zea mays: Exserohilum turcicum pathosystem. Genet Mol Biol. 28: 435-439.

Poland JA, Bradbury PJ, Buckler ES, Nelson RJ (2011) Genome-wide nested association mapping of quantitative resistance to northern leaf blight in maize. Proceeding of the National Academy of Sciences United State of America. 108: 6893-6898.

Ramalho MAP, Abreu AFB, Santos JB, Nunes JAR (2012) Genética quantitativa em plantas autógamas. Lavras: Ed. UFLA. 522p.

Resende MDV (2008) Genômica quantitativa e seleção no melhoramento de plantas perenes e animais. Colombo: Embrapa Florestas.

Resende Júnior MFR, Alves AA, Sánchez CFB, Resende MDV, Cruz CD (2013) Seleção genônima ampla. In: Cruz CD, Salgado CC, Bhering LL. (Eds.). Genômica aplicada. Viçosa, UFV. 10: 375-424.

Santos JS (2016) Análise dialélica completa e recíproca na estimação da capacidade combinatória da incidência e severidade de Bipolaris maydis e Exserohilum turcicum em milho-pipoca em diferentes épocas de cultivo. 2016. 83f. Dissertação (Mestrado em Genética e Melhoramento de Plantas) - Universidade Estadual do Norte Fluminense, Rio de Janeiro.

Schipanski CA (2011) Manual de identificação e manejo das doenças do milho. 3. ed. Castro: Fundação ABC. 126 p.

Silva DD, Cota LV, Costa RV (2015) Doenças. In: Silva, D.D.; Cota, L.V.; Costa, R.V. Cultivo de milho. 9. Ed. Sete Lagoas: Embrapa Milho e Sorgo. (Sistemas de produção, 1).

Souza IRP, Schuelter AR, Guimarães CT (2004) Genética da resistência a doenças, com ênfase na virose mosaicocomum do Milho. In: Oliveira E and Oliveira CM. Doenças em milho. Molicutes, vírus, vetores e mancha por phaeosphaeria. Brasília, DF, p. 227-252.

Van Inghelandt D, Melchinger AE, Martianant JP, Stich B (2012) Genome-wide association mapping of flowering time and northern corn leaf blight (Setosphaeria turcica) resistance in a vast commercial maize germplasm set. BMC Plant Biol. 12: 56-71. 
Vieira RA (2010) Melhoramento genético da resistência à helmintosporiose comum, cercosporiose e ferrugem polissora em milho-pipoca. 2010. 86f. Dissertação (Mestrado em Genética e Melhoramento) - Universidade Estadual de Maringá, Maringá.

Vieira RA, Tessmann DJ, Hata FT, Souto ER, Mesquini RM (2009) Resistência de híbridos de milho-pipoca a Exserohilum turcicum, agente causal da helmintosporiose do milho. Scientia Agraria. 10: 391-395.

Vivek B, Odongo O, Njuguna J, Imanywoha J, Bigirwa G, Diallo A, Pixley K (2010) Diallel analysis of grain yield and resistance to seven diseases of african maize (Zea Mays L.) inbred lines. Euphytica. 172: 329-340.
Xu Y, Skinner DJ, Wu H, Palacios-Rojas N, Araus JL, Yan J, Gao S, Warburton ML, Crouch JH (2009) Advances in maize genomics and their value for enhancing genetic gains from breeding. Int J Plant Genomics. 2009: 1-30.

Wang H, Xiao ZX, Wang FG, Xiao YN, Zhao JR, Zheng YL, Qiu FZ (2012) Mapping of HtNB, a gene conferring nonlesion resistance before heading to Exserohilum turcicum (Pass.), in a maize inbred line derived from the Indonesian variety bramadi. Genet Mol Res. 11: 2523-2533.

Wang P, Souma K, Kobayashi Y, Iwabuchi K, Sato C, Masuko T (2010) Influences of northern leaf blight on corn silage fermentation quality, nutritive value and feed intake by sheep. Animal Sci J. 81: 487-493. 